\title{
Analysis of Actor Networks in the Development of Kandri Tourism Village, Gunungpati District, Semarang City
}

\author{
Tri Yuniningsih ${ }^{1}$, Herbasuki NC ${ }^{2}$, Damaris Bernike Bellastuti ${ }^{3}$ \\ \{ ibutriyuniningsih@gmail.com ${ }^{1}$, herbasuki@gmail.com ${ }^{2}$, DamarisBellastuti@yahoo.com $\left.{ }^{3}\right\}$ \\ ${ }^{1)}$ Lecturer at the Public Administration Department, Diponegoro University, Indonesia \\ 2) Lecturer at the Public Administration Department, Diponegoro University, Indonesia \\ ${ }^{3)}$ Students of the Public Administration Department, Diponegoro University, Indonesia
}

\begin{abstract}
In the development of Kandri Tourism Village, it involves many actors / stakeholders. However, in the implementation of its activities, many problems are faced such as disharmony, lack of coordination and violating agreements. Therefore, the purpose of this study is to analyze the actor network in the development of the Kandri Tourism Village in the city of Semarang. The method used is descriptive qualitative. The results showed that the development of the Kandri Tourism Village involved many policy actors with the stages of the actor network formed in the development of the Kandri Tourism Village consisting of 9 (nine) stages, including Punctualization, Translation, Problematization, Interessment, Enrollment, Inscription, Speaker / Delegate, Betrayal. and Irreversibility. Suggestions that can be recommended are the need for active participation from the Semarang City Culture and Tourism Office in mediating conflicts between Pokdarwis. The importance of legalization from the Semarang City Government as a follow-up to the Regional Regulation of the Province of Central Java Number 2 of 2019 concerning Empowerment of Tourism Villages in Central Java Province Article 14, which only allows one tourist manager in one area.
\end{abstract}

Keywords: Role, Actor, Actor Network, Development, Tourism Village

\section{Introduction}

Tourism is also one of the strategic sectors in regional economic development because this sector contributes to Regional Original Income (PAD). Semarang City is listed as the Regency / City Governmentwith the largest Regional Original Revenue (PAD) in Central Java Province in 2018 . Based on data from the Directorate General of Fiscal Balance of the Ministry of Finance, Semarang City's PAD reached Rp 1.72 trillion in 2018 or around 13\% of the total $\mathrm{PAD}$ of 35 regencies / municipalities in Central Java. The average contribution of the tourism sector in the revenue of Semarang City's PAD annually is $0,40 \%$.

B ome recent years, the City Government of Semarang focus unt uk work on the tourism sector to revitalize a number of objects and tourist areas in Semarang who previously have not been optimally constructed, such as the revitalization of the Old Town, Forest Tourism Tinjomoyo, initiation hundreds Kampung Thematic, to revitalize the West Flood Canal through Devel gunan Semarang Bridge Fountain. Sourced from the Central Java Tourism Statistics 
Book 2015-2018, it can be seen that the number of visitors is increasing from year to year. However, the growth is still said to be fluctuating and even declining for the development of foreign tourists. For example, in 2018 there was a drastic decrease of $33.41 \%$ to only 66,107 foreign tourists visiting Semarang City. On the other hand, there is a positive trend for the development of Indonesian tourists every year. The increase in the number of tourists visiting the city of Semarang cannot be separated from the interest in existing tourist objects .

One of the objects wi sata in the city of Semarang is the Tourism Village Kandri determined through Letter Decree No. 556/407 Waikota 2012. Concerning Determination Kandri village and sub-district Nongkosawit Gunungpati Village, Village Wonolopo Mijen District of Seb agai Semarang Tourism Village. Kandri has the status of a sub-district but in tourism development it is called the Kandri Tourism Village. Kandri Tourism Village began with the construction of a reservoir that submerged an agricultural area and made residents of Kandri Village lose part of their livelihoods as farmers. However, this actually has a positive impact on residents because in addition to the function of the reservoir as a reservoir for water, it also has other functions as an object and an artificial tourist attraction. This is then used as a business opportunity by empowering the creative economy of the community through tourism businesses by forming community -based tourism villages .

Kandri Tourism Village initially had 1 (one) pokdarwis, namely Pokdarwis Pandanaran, whose members consist of RW 1 to RW 4. However, in 2014 a new pokdarwis named Pokdarwis Suko M akmur emerged, most of which were community members of RT 05 RW III. Pokdarwis Suko Makmur offers water tours by boat around the Jatibarang Reservoir. Meanwhile, Pokdarwis Pandanaran continues to optimize educational tourism on livestock, farming and culture. The existence of institutional conflicts in the management of the Kandri Tourism Village due to differences in opinion between Pokdarwis Pandanaran and Pokdarwis Suko M akmur had caused disharmony, lack of cooperation or good coordination.

Tourism Village Development Kandri continue to be done by involving the actor / stakeholder $s$ another. Partnerships or cooperation are established with several parties, including the government, the private sector, and universities. The government plays a role in implementing policies and supporting facilities, both physical and non-physical. Most of the partnerships that involve non-government actors are through the provision of Corporate Social Responsibility (CSR) funds provided by private partners to the people of Kandri Tourism Village. Several private parties, including PT Pertamina MOR IV Central Java and DIY and PT Angkasa Pura I Ahmad Yani International Airport Semarang. Partnerships with universities are also carried out and focus on activities for developing human resources (HR) or community empowerment, through training activities and real work lectures $(\mathrm{KKN})$. Universities that have partnered with Wisat a Kandri Village include Semarang State University, Soegijaprana Ta University, Diponegoro University, UIN Walisongo, and Semarang State Polytechnic.

The development of the Kandri Tourism Village also experiences obstacles such as limited land, limited budget, limited human resources, mindset, regulations, promotional activities, and cooperation among stakeholders. This is supported by research [1] that had the title Analysis of the Partnership in the Management of Tourism Village Kandri District of Gunungpati Semarang who say that the lack of role of stakeholders of tourism to develop the rural tourism, yet the establishment of coordination between government agencies, Pokdarwis and society, as well as partnerships most of which are provided by the private sector through Corporate Social Responsibility (CSR) to the community through pokdarwis . The research conducted by [2] in the title of Tourism Village Object Development Strategies, Gunung Pati District, Semarang City also resulted that in developing Desa Wisata Kandri there were several obstacles 
faced, namely the involvement of stakeholders in the development of tourism villages, quality and the quantity of human resources is inadequate, the need for special training for personnel in the field, limited budget from the Government, inadequate facilities and infrastructure, minimal information media, and the community does not want to cooperate with outside parties. The large number of actors involved in the development of the Kandri Tourism Village also creates complex problems in the formed actor network such as differences of opinion, overlapping roles, poor communication, or limited costs / human resources in the partnership.

Research entitled Analysis of the Role of Stakeholders in the Development of Tourism Objects for Karang Jahe Beach in Rembang Regency by Fitri [3]. This research uses a qualitative approach method. This research results that for tourism development there are primary, key and secondary stakeholders where the three of them have important roles that are mutually synergistic between one another. There are several factors that hinder stakeholders in developing tourist objects, namely land, budget, human resources and cooperation between stakeholders .

Research conducted by Tri Yuniningsih, Titi Darmi, and Susi Sulandari with the title Pentahelic Model in Tourism Development in Semarang City in 2019 supports the research conducted by the author in determining actor indicators. Researchers used the theory of policy actors according to [4] [5]. namely elected officials, appointed officials, interest groups, research organizations, and mass media. The second theory used is the Pentahelix theory according to Arif Yahya, which is collaboration with 5 (five elements), namely: Academician, Business, Community, Government and Media. From the research it can be seen that the development of tourism in the city of Semarang uses the pentahelix model, which has involved academics, government, community, business, and the mass media.

This research on sustainable tourism stakeholders with the title Stakeholders in a Tourist Destination - Matrix of Possible Relationships Towards Sustainability , compiled by Iva Slivar is in line with previous research. This study uses the theory of the theory used according to Cooper, Fletcher, [6] stated that stakeholders in sustainable tourism development, namely local residents, tourists, the tourism industry, the public sector and others as the main stakeholders in tourism. This study developed a matrix by asking tourism experts to show key interactions between the two players. The focus of this paper will be on two-way objective stakeholder collaboration, presented systematically in a typical relationship matrix, representing its theoretical contribution. A panel of experts from academia, practice and the public sector developed a relationship matrix with the scope of spreading various forms of collaboration between stakeholders aimed at bringing together the right balance needed for sustainable development in tourism.

Research conducted by [7] entitled Using actor-network theory to understand interorganizational network aspects for strategic information systems planning uses Actor-network theory (ANT) in its discussion. The research approach used begins with a literature review and research question formulation. The results show that ANT provides the right way to understand networks as heterogeneous network actors, and network evolution as a translation process, which includes four elements: problematization, registration interessement, and mobilization .

Synergy between actors in the development of a tourist village is an important thing to create. The existence, impact, and lightness that is formed will affect how these efforts can run smoothly. The involvement of actors in the network can be reviewed using several theories in Public Administration Science, one of which is the actor network theory. Actor-network theory (Actor Network Theory) will try to explore the relational relations between actors in particular in the study on the development of tourism village 
Kandri. D nature of this research will focus on the analysis phase of an network of actors that are formed in the development of the village of W isata Kandri .

\subsection{LITERATURE REVIEW}

\section{Actor Network / Actor Network Theory (ANT)}

In [8] through Home Visits network a ktor or Actor Network Theory (ANT) is an approach that comes from the field of science studies, which treat the object as part of a social network. J concept ejaring - actor first conceived by Michel Callon, Bruno Latour and John Law in 1980 - an. Using the actor network metaphor, the ontological assumption used by actor network theory is that reality (social, organizational, technological, etc.) is all just the result or result of a relationship between various types of entities, both material and human. All entities involved in this network are hereinafter referred to as "actors".

According to Latour in [8], ANT theory does not usually explain why or how the network was formed . The opposite is really a way to explore relational relationships in a network which can be a lot of different things. Meanwhile, according to Riyanto in [8] there are several stages that need to be considered in actor network theory:

1. The first stage, Punctualization is the process of treating heterogeneous networks as an individual actor to reduce network complexity This step is very important in conducting research as a simplification of drawing conclusions. The complexity of the network in which one main actor has many actors behind it as a result of aligning interests and agreeing to join forces to become so complex, especially since the network does not only consist of material but also non-material, so this step is a simplicity of treating heterogeneous networks as an individual actor.

2. The second stage, Translation, is a process of aligning the desires of various actors and the desires of the main actors. Creation of a network of actors. This process consists of three main stages: issues, interests, and roles. Most actors in organizations are involved in different translation processes, each actor has unique characteristics and outcomes. To clarify, the use of focus on one actor is very useful, from which the vantage point is where the translation process is seen.

3. The third stage, Problematization. After the translation process, the actor defines the interests of other actors that are consistent with his own interests. At this stage one or more key actors formulate the problem and define the role of other actors in solving the problem that he proposes. The solution is proposed in such a way that all actors involved are bound to a centralized control mechanism called an obligatory passage point (OPP). The merger of agreed forces by equating problems with different interests results in a division of roles in its achievement. To reach an agreement, a second moment of translation is needed, namely Interessment .

4. The fourth stage, Interessment, the second moment of translation involving pross menyakinka n actors- other actors to accept the definition of local actors. The second moment is the next step in the first moments of translation which at this moment the main actor trying to convince other actors to download e rima definition, how, how, and when to achieve this common goal. Who gets what, who does what with various deals and promises offered to convince other actors.

5. The fifth stage, Enrollment. The third moment of translation, where other actors in the network receive (or align with) the interests assigned to them by the main actor. With various attractive offers that are exchanged with resources owned by other actors to become a common force, the third moment is the moment when other actors accept and become a 
new network that has the same problems. Achieving the interests of each actor, the roles performed by each actor, how the network is formed, who gets what and various offers and promises are agreed at this moment.

6. The sixth stage, Inscription. A process of creating artifacts that will ensure the protection of certain interests. The agreement that was formed in the third moment was continued by Inscription. The process by which there is an agreement to ensure the achievement of the interests of each actor. This inscription can be in the form of a paper containing an agreement or just an oral agreement. An oral agreement without witnesses is an inscription that requires a high level of trust so that there is no betrayal process after common goals have been achieved, however, on many occasions, oral agreements without witnesses have resulted in many network breakdowns.

7. Seventh stage, Speaker / Delegate representative actors who speak on behalf of (or stand for) other actors. The actor, who spoke on na $\mathrm{m}$ a another actor $\mathrm{b}$ isa is the main actor or $\mathrm{p}$ oles provided by the main actors are the other actors as a spokesman for a special, who is the spokesman and at the level of what is delivered is a decision of the network, when the primary actor should speak when another actor becomes the spokesperson.

8. The forward stage, Betrayal. A situation where the actor does not comply with the agreement arising from the participation of representatives. This situation is due to the failure to carry out the initial agreement and to leave the inscription made in exchange for handing over resources to the main actors. Whether there is inscription in written form or not all of them have the risk of betrayal by the main actor.

9. Phase case e $\mathrm{mb}$ i lan, irreversibility. The next level allows for a return to the point where alternative possibilities exist. According to Walsham and Sahay $(1999,42)$, alignment can occur again after irreversibility, namely where the broken network reunites the forces. This return point can occur if the problems that make the actor leave the network are repeated and can be started from the initial steps of translation and still have the risk of betrayal. Actor Network Theory (ANT) looks at how the network overcomes obstacles and gets coherence and consistency (stable), how to arrange (bring elements closer) and convert (translate) network elements. How to ask other people to follow the program that is launched, how to give the quality and motivation of the actors (determine what is appropriate for the role), how other people can be useful, and how to function.

\subsection{Tourism Village}

ATourism Village is a rural area that offers an entire atmosphere that reflects the authenticity of the village itself, starting from socio-culture, customs, daily life, having a distinctive building architecture and village spatial structure. socioeconomic life or economic activities that are unique and attractive and have the potential to develop various components of tourism, for example attractions, accommodation, food and beverages, souvenirs and other tourism needs.

S edangkan according [9] Tourism Village is a development of rural areas which basically does not change what is already there but more likely to develop the potential of the existing village by making use of the ability of the elements that exist in the village that serves as tourism product attributes on a small scale become a series of tourism activities or activities and are able to provide and fulfill a series of travel needs both from the aspect of attraction and as supporting facilities. 


\section{Methodology}

This research is a descriptive qualitative research type. L Okus Kandri research at the Tourism Village, District Gunungpati, Semarang. Data sources consist of primary data obtained from direct research informants, and secondary data obtained through documentation and other sources that can provide information related to the focus of the study. P Collecting data is done by observation, w Interview and documentation. The data analysis process adopted the thoughts of Miles and Huberman [10] namely; data condensation, data presentation, and drawing conclusions. The validity of the data used in this study was to use source triangulation techniques.

\section{Finding and Discussion}

Kandri Village or Kandri Tourism Village is a village located in Gunungpati District, Semarang City which has the potential for natural tourism in Goa Kreo and Jatibarang Reservoir. The Semarang City Government in collaboration with Japan in 2010 made the Jatibarang reservoir. The construction of the reservoir aims to control floods, provide raw water in the city of Semarang, as well as increase the sustainability of the conservation function in the watershed (DAS). The construction of the reservoir turned out to have a negative impact on the agricultural land of the Kandri residents, all agricultural land sank due to the overflow of the reservoir, thus causing the majority of the community to lose their jobs as farmers . P there in 2012 Semarang City Government through Mayor of Semarang Decree No. 556/40 December 21, 2012 on the establishment of the District Sub Kandri Gunungati Semarang as in the dictum One Mayors Semarang, it was decided: "Kandri village as tourism village-based and based Natural Fascination Cultural Arts Attraction". Therefore the people of Kandri form a Tourism Awareness Group or often called Pokdarwis Pandanaran to empower local people to explore more of their potential, creating an alternative to empower the people's economy in the tourism sector. The presence of a tourist village is a conditioning for the city community, this is because the Kandri Tourism Village offers an original village atmosphere that is cool, busy, beautiful and green.

The actor network is formed consisting of several stages, including Punctualization, Translation, Problematization, Interessment, Enrollment, Inscri ption, Speaker / Delegate, Betrayal, and Irreversibility according to the opinion of Latour: Actor-Network Theory in [8]. The stages of the actor network formed in the development of the Kandri Tourism Village are as follows:

a. Punctualization

Punctualization is the initial identification stage of the actor network that is formed, namely by determining the network and determining the main and supporting actors in the development of the Kandri Tourism Village. In this research, the network formed was a network of actors involved in the development of the Kandri Tourism Village. Kandri Tourism Village was formed because some people lost their jobs due to the construction of the Jatibarang Reservoir so that people looked for other alternative jobs by utilizing existing potentials such as nature, history, and culture to be used as tourist destinations. The initiation of the establishment of the Kandri Tourism Village came from the community and government. This means that there is potential in Kelurahan Kandri and the community 
is willing to initiate and manage, while on the government side, in this case the Semarang City Culture and Tourism Office facilitates or provides assistance in the formation of a tourist village.

The Semarang City Regional Development Agency (Bappeda) together with the Semarang City Culture and Tourism Office and other Regional Apparatus Organizations (OPD) conducted a feasibility assessment before establishing Kandri Village as a wista village. The feasibility assessment is in the form of assessing tourist attractions, the availability of infrastructure such as transportation facilities and services, electricity, clean water, waste management, and tourism management institutions. Kandri Tourism Village was inaugurated using a Waikota Decree (SK) Number 556/407 of 2012 concerning the Determination of Kandri and Nongkosawit Villages, Gunungpati District, Wonolopo Village, Mijen District as Tourism Villages in Semarang City.

In the development of the Kandri Tourism Village, several other actors are involved due to limited Human Resources (HR) and / or funds or costs. In this study, Pokdarwis Pandanaran, Department of Culture and Tourism Semarang role as the lead actor. Meanwhile, the Semarang City Development Planning Agency (Bappeda), Semarang Agriculture Office and Semarang City Cooperatives and MSMEs Office, Kandri Village, Central Java Youth, Sports and Tourism Office, Semarang State University, PT Pertamina MOR IV Central Java and DIY, PT Angkasa Pura I Ahmad Yani International Airport Semarang, Alfamart and AyoSemarang.com as supporting actors. Each office has their respective roles in the development of the Kandri Tourism Village in accordance with their functional duties and authorities

b. Translation

Translation is a process of aligning the desires of various actors with the desires of the main actor. This stage is to determine and describe the desires of the main and supporting actors, adjust the desires of the supporting actors with the main actors and determine the subject matter, determine their respective interests , and determine the role of the actors .

In this study, Pokdarwis Pandanaran and the Semarang City Culture and Tourism Office, which are the main actors, have an interest in Kandri Tourism Village to develop. However, in practice the main actors cannot work alone due to limited human resources or costs. Therefore, there are supporting actors who help develop the Kandri Tourism Village. Each of the supporting actors has their own interests. Semarang City Development Planning Agency (Bappeda), Semarang City Agriculture Office and Semarang City Cooperatives and MSMEs Office as a structural institution of the Semarang City Government, Kandri Village as a village level government, the Youth, Sports and Tourism Office of Central Java as a structural institution for the Central Java Provincial Government have interests that are carried out in accordance with their respective duties, functions and authorities as regulated in accordance with law. Semarang State University as a university has the obligation to carry out tridharma such as research and community service, PT Pertamina MOR IV Central Java and DIY, PT Angkasa Pura I Ah mad Yani International Airport Semarang as a State-Owned Enterprise (BUMN) and Alfamart as a limited liability company carries out its obligations through Corporate Social Responsibility (CSR) and the AyoSemarang .com media function as media.

c. Problematization

Problematization is p roses define the interests of other actors is consistent with its own interests and establish itself as an "obligatory passage point" (OPP). In this stage, the main actor describes and understands the interests of other actors and makes the main actor 
a reference / center for consideration in the development of the Kandri Tourism Village. In this study, supporting actors who will work and activities at the Tourism Village Kandri least berkoordiasi by Pokdarwis Pandanaran and / or D carbuncle of Culture and Tourism of Semarang city is becoming the main actor. Supporting actors will ask what is being needed by Kandri Tourism Village to the main actors, especially Pokdarwis Pandanaran because they know the needs or obstacles in the development of the Kandri Tourism Village. Then the main actors will give considerations according to the interests and capacities of each supporting actor.

d. Interessment

Interessment mer upakan moment of convincing actors- actors in the network to accept the definition of the main actors. In this stage, the main actors supporting actors convincing to accept a definition of the problem, how to settle how to carry out, where and wak $\mathrm{t} u$ to reach the destination as well as any actor get the rights and obligations and the other agreements. Pokdarwis Pandanaran and the Department of Culture and Tourism of Semarang City as the main actors convinced other supporting actors to partner / cooperate in developing Kandri Tourism Village. Pokdarwis Pandanaran and the Semarang City Tourism Culture Office will reveal what are the problems and needs to support Kandri Tourism Village and offer alternative assistance that can be provided by supporting actors.

e. Enrollment

Enrollment namely actors- actors la in the network receives butterfly ntingan assigned to them by the main actors. Supporting actors in the network accept / align the interests applied to them by the main actors. A new network is formed which has the same problems and other agreements. Each supporting actor provides assistance according to their respective interests and capacities in the development of the Kandri Tourism Village, be it government, private sector, universities and the media.

f. Inscription

The process of creating artifacts to ensure the protection of certain interests. Every collaboration that is formed through an agreement such as an agreement or MoU (Memorandum of Understanding). The agreement or MoU (Memorandum of Understanding ) contains information from each actor involved along with their rights and obligations, assistance provided, and the period of cooperation.

g. Speaker / Delegate

Speaker / Delegate is t AHAP where the actors speak in the name or talk to other people. Understand the differences between main actors / supporting actors / spokespersons. The network also decides when and where and at what level the actor can become a spokesperson. In Kandri Tourism Village, there is an actor who becomes the spokesperson for this actor network, namely Pokdarwis Pandanaran. Pokdarwis Pandanaran as the manager of the tourism village was given the trust to represent the network of actors that were formed, because they as managers of the tourism village knew what was needed and what was happening in the Kandri Tourism Village.

h. Betrayal

Betrayal is a situation where actors do not comply with agreements arising from the participation of their representatives. As far as the actor network that was formed in the development of the Kandri Tourism Village, there was a conflict which resulted in the 
existence of two pokdarwis institutions in one area, namely Pokdarwis Pandanaran and Pokdarwis Suko Makmur. Pokdarwis Suko Makmur which consists of the people of RT 05 RW 3 Kelurahan Kandri has a disagreement with Pokdarwis Pandanaran, they wish to exploit the tourism potential near Jatiarang Reservoir by boat tours, while Pokdarwis Pandanaran refuses and still wants to develop education. This institutional conflict had caused a bad relationship between the two of them.

i. Irreversibility

Irreversibility is t ingkatan further allows to return to tingka t where alternative possibility is still there. Reconciliation can occur again after irreversibility. In every actor network that is formed there is always the possibility of returning at this stage. This stage applies to a number of new supporting actors who wish to be involved in the development of the Kandri Tourism Village.

\section{Conclusion}

Stages actor network formed d natural development Kandri Tourism Village consists of 9 (nine ) stages, among others Punctualization, Translation, Problematization, Interessment, Enrollment, Inscription, Speaker / Delegate, Betrayal and Irreversibility. Punctualization is the initial identification stage of the actor network that is formed.Pokdarwis Pandanaran, Department of Culture and Tourism of the City of Semarang plays the main actor. At the Translation stage, Pokdarwis Pandanaran and the Semarang City Culture and Tourism Office, which are the main actors, cannot work alone due to limited human resources or funding. At the Problematization stage, the main actor describes and understands the interests of other actors and makes the main actor a reference / center for consideration in the development of the Kandri Tourism Village. The Interessment stage where Pokdarwis Pandanaran and the Semarang City Tourism Culture Office convinced other supporting actors to partner / cooperate in developing the Kandri Tourism Village. In the Enrollment stage, each supporting actor provides assistance according to their respective interests and capacities in the context of developing Kandri Tourism Village. At the Inscription stage there is an agreement or MoU ( Memorandum of Understanding ) containing information from each actor involved along with their rights and obligations, assistance provided, and the period of cooperation. In Stage Speaker / Delegate, Pokdarwis Pandanaran entrusted u nt uk represents the actor network is formed. At the Betrayal stage, there was a conflict which eventually resulted in the existence of two pokdarwis institutions in one area, namely Pokdarwis Pandanaran and Pokdarwis Suko Makmur. Irreversibility applies to the existence of new supporting actors who want to be involved in the development of the Kandri Tourism Village.

Based on the results of research found in the field, efforts to overcome several inhibiting factors in the development of Kandri Tourism Village, including:

1. The Central Java Provincial Government must immediately make regulations governing tourist villages in urban areas so that they can access the financial assistance provided. The Semarang City Government can also compile local regulations regarding tourist villages so that they can become a legal umbrella for their journey.

2. Should a danya implementation of good regulation in Perat Uran Java Province Number 2 Year 2019 About Empowerment Village Tourism in Central Java province Article 14 that there should only be one knowl lola travel in one area. 
3. Need for cooperation and good communication between Pokdarwis Pandanaran and Pokdarwis Suko Makmur in maximizing the potential of tourism village in order kesejahtera Kandri an increase as the surrounding community research agreement a tour package, promotion media.

\section{References}

[1] Y. Isnaningtyas and N. Marlina, "Analisis kemitraan dalam pengelolaan Desa Wisata Kandri Kecamatan Gunungpati Kota Semarang,” J. Polit. Gov. Stud., vol. 6, no. 03, pp. 551-560, 2017.

[2] M. Tofan, A. Subowo, and M. Maesaroh, "Strategi Pengembangan Obyek Desa Wisata Kandri Kecamatan Gunung Pati Kota Semarang,” J. Public Policy Manag. Rev., vol. 3, no. 2, pp. 368-378, 2014.

[3] F. Handayani and H. Warsono, "Analisis Peran Stakeholders Dalam Pengembangan Objek Wisata Pantai Karang Jahe Di Kabupaten Rembang," J. Public Policy Manag. Rev., vol. 6, no. 3, pp. 40-53, 2017.

[4] H. Ramesh M , Dan, Studying Public Policy: Policy Cycles and Policy Subsystem. Oxford, England: Oxford University Press, 1995.

[5] S. Suwitri, "JEJARING KEBIJAKAN DALAM PERUMUSAN KEBIJAKAN PUBLIK Suatu Kajian Tentang Perumusan Kebijakan Penanggulangan Banjir dan Rob Pemerintah Kota Semarang,” J. Deleg. J. Ilmu Adm. STIA Banjarmasin, vol. 6, no. 3, pp. 01-32, 2008.

[6] C. C Fletcher, J., Gilbert, D., and Wanhill, S, Tourism: Principle and Practice. Longman Group Limited, 1993.

[7] D. Hu, Master thesis: "Using actor-network theory to understan inter-organizational network aspects for strategic information systems planning. Iserlohn, Germany: BiTS Business and Information Technology School, 2011.

[8] T. Yuniningsih and S. S. Titi Darmi, "Model Pentahelik Dalam Pengembangan Pariwisata Di Kota Semarang," J. Public Sect. Innov., vol. 3, pp. 84-93, 2019.

[9] A. J. Muljadi, Kepariwisataan dan Perjalanan: Cetakan ketiga. Jakarta: Rajagrafindo Persada, 2012.

[10] S. Sugiyono, Metode penelitian kuantitatif dan kualitatif dan R\&D. 2010. 